\title{
CORRECTIVE EFFECT OF RED WINE CONCENTRATE ENRICHED WITH NATURAL COMPLEX OF POLYPHENOLS ON ACTIVITY OF ANTIOXIDANT DEFENSE ENZYMES IN CARDIAC MUSCLE UNDER EXPERIMENTAL DIABETES MELLITUS
}

\author{
D. Yu. Hertsyk ${ }^{\circledR 1 *}$, M. V. Sabadashka ${ }^{\circledR 1}$, L. V. Kaprelyants ${ }^{(2)}$, N. O. Sybirna®1 \\ ${ }^{1}$ Ivan Franko National University of Lviv, 4 Hrushevskyi St., Lviv 79005, Ukraine \\ 2 Odesa National Academy of Food Technologies \\ 112 Kanatna St., Odesa 65039, Ukraine \\ ${ }^{*}$ Corresponding author e-mail: Dariya.Hertsyk@Inu.edu.ua
}

Hertsyk D.Yu., Sabadashka M.V., Kaprelyants L.V., Sybirna N.O. Corrective effect of red wine concentrate enriched with natural complex of polyphenols on activity of antioxidant defense enzymes in cardiac muscle under experimental diabetes mellitus. Studia Biologica, 2021; 15(1): 37-48 • DOI: https://doi.org/10.30970/sbi.1501.644

Background. Diabetes mellitus is accompanied by oxidative-nitrative stress, which is caused both by an increased generation of the Reactive Oxygen Species and the Reactive Nitrogen Species under the conditions of this pathology and by the disorders of the antioxidant defense system, especially its enzymatic part. This leads alterations in the morpho-functional state of cells, organs, and the whole organism. Free radicals are involved in the destruction of pancreatic cells in type 1 diabetes mellitus, which leads to even greater inhibition of insulin secretion, worsening of the course of the disease and occurrence of diabetic complications. The complications of diabetes mellitus include often diagnosed cardiovascular diseases. Therefore, the use of treatments characterized not only by hypoglycemic properties for normalization of blood sugar level in diabetes mellitus, but also by antioxidant properties for normalization of oxidative/antioxidant balance of the organism in the studied pathology can be promising. Scientists pay a great attention to the study of substances with such properties, especially natural phenolic compounds of grape, which are also characterized by immunomodulatory properties.

Materials and Methods. The study was performed on cardiac tissues of control rats, control animals treated with wine polyphenolic complex concentrate, animals with streptozotocin-induced diabetes mellitus and animals with experimental diabetes mellitus

(C) 2021 D. Yu. Hertsyk et al.; Published by the Ivan Franko National University of Lviv on behalf of Біологічні Студії / Studia Biologica. This is an Open Access article distributed under the terms of the Creative Commons Attribution License (http://www.budapestopenaccessinitiative.org and Creative Commons Attribution 4.0 License), which permits unrestricted reuse, distribution, and reproduction in any medium, provided the original work is properly cited.

ISSN 1996-4536 (print) • ISSN 2311-0783 (on-line) • Біологічні Студії / Studia Biologica • 2021 • Том 15 / № 1 • С. 37-48 
treated with a concentrate of wine polyphenolic complex. The activity of catalase, superoxide dismutase, glutathione peroxidase and glutathione reductase were detected to examine the corrective effect of the concentrate of red wine natural polyphenolic complex on the state of the enzymatic part of the antioxidant defense system.

Results. The results have shown the normalization of activity of catalase, superoxide dismutase, and changes in the activity of enzymes of glutathione cycle after oral administration of polyphenolic complex concentrate for 14 days to rats with streptozotocin-induced diabetes mellitus.

Conclusions. The results confirm a hypothesis about the antioxidant effect of the studied concentrate and the ability of natural polyphenolic complexes to serve as the basis for new drugs for treatment of diabetes-induced disorders.

Keywords: diabetes mellitus, polyphenolic compounds, antioxidant system

\section{INTRODUCTION}

Diabetes mellitus (DM) is a chronic endocrine and metabolic disease caused by an impact of endogenous and exogenous factors with an absolute or relative absence of insulin that leads to disorders of all metabolic processes [4, 25]. The number of people with this pathology increases dramatically every year, and according to the World Health Organization (WHO), there are more than 400 million people on the Earth with this disease [5]. Approximately $10-15 \%$ of all people with this disease are people with type $1 \mathrm{DM}$.

Persistent hyperglycemia, which is typical of this pathology, not only activates the generation of free radicals, but also reduces the activity of cellular antioxidants, such as catalase (CAT), glutathione peroxidase (GPx), superoxide dismutase (SOD), and others [14, 21].

Therefore, it is important to develop new antidiabetic drugs. These agents are not only supposed to decrease the level of peripheral blood glucose, but also correct metabolic and morpho-functional disruption of cells. Additionally, they must help to maintain the oxidative-antioxidant balance and prevent the development of oxidative stress. Since the role of Reactive Oxygen Species (ROS) in the pathogenesis of DM and its complications is beyond doubt, the application of antioxidant therapy is one of the required parts of complex therapy of DM and its complications [13]. Today, scientists pay more and more attention to various herbal remedies, especially to natural polyphenolic complexes. Red grape wine contains a particularly large number of such compounds. Polyphenolic compounds of grape juice, including proanthocyanidins, flavan-3-ol derivatives, and other flavonoid derivatives, which have an effect in preventing cardiovascular diseases, have been subject to numerous studies [11].

Grape polyphenols interact with blood plasma proteins and blood cells to prevent premature oxidation of their molecules caused by oxidative stress. In addition, the powerful bactericidal and antiviral activities of these compounds were determined. The protective effect of grape polyphenols in some systems and organs under conditions of oxidative stress at diabetes mellitus was revealed [11].

It should be noted that almost $63 \%$ of all phenolic substances during the production of wine, especially large amounts of procyanidins of grape seeds and berry skins are

ISSN 1996-4536 (print) • ISSN 2311-0783 (on-line) • Біологічні Студії / Studia Biologica • 2021 • Том 15 / № 1 • С. 37-48 
converted into wine, so the multicomponent concentrate obtained from such wine can be considered as one of the most effective natural remedies [22].

The aim of this study was to determine biochemical mechanisms of action of red wine concentrate that contains a large amount of phenolic compounds, herein referred to as natural complex of polyphenols (NCP). The impact of NCP on the activity of antioxidant enzymes in heart tissue under experimental DM was studied.

\section{MATERIALS AND METHODS}

The experiments were performed on white outbred male rats weighing 100-150 g. The research was performed according to the General principles of experiments on animals approved by the First National Congress on Bioethics (Kyiv, Ukraine, 2001) in agreement with the guidelines of Directive 2010/63/EU of the European Parliament on the protection of animals used for scientific purposes and the Law of Ukraine "On Protection of Animals from Cruelty" of February 26, 2006, and also approved by the Ethics Committee of Ivan Franko National University of Lviv, Ukraine (protocol No. 17-01-2021 of January 17, 2021).

Dry red wine for experiments was provided by Odesa National Academy of Food Technologies (Ukraine).

The concentrate was obtained by evaporating wine on a rotary evaporator Laborota 4001 (Germany) at a temperature of $40{ }^{\circ} \mathrm{C}$ and pressure of $0.8-0.9 \mathrm{~kg} / \mathrm{cm}^{2}$. Evaporation was carried out from $1 \mathrm{~L}$ of wine to $300 \mathrm{~mL}$ of the concentrate. The concentrate was stabilized with ethanol up to $30 \%$ and with biogenic surfactants PS (surface-active products of biosynthesis of Pseudomonas sp. PS-17) up to 3\% [28].

The total polyphenol content in the wine and the obtained concentrate was standardized using Folin-Ciocalteu reagent according to gallic acid equivalent [26]. The concentration of polyphenols in the obtained concentrate was $53.36 \mathrm{mg} / \mathrm{mL}$.

Experimental DM was induced by intraabdominal injection of Streptozotocin (Sigma, USA) dissolved in a $10 \mathrm{mM}$ citrate buffer ( $\mathrm{pH} \mathrm{5.5)} \mathrm{at} \mathrm{a} \mathrm{dose} \mathrm{of} 60 \mathrm{mg} / \mathrm{kg}$ of body weight. The induction of DM was controlled according to blood glucose level, which was measured $72 \mathrm{~h}$ after Streptozotocin injection. Animals with glucose concentration $12 \mathrm{mmol} / \mathrm{L}$ and higher were used for the research. Glucose concentration was determined by glucose oxidase method using a detection kit (Filisit diagnostics, Ukraine).

Experimental rats were divided into 4 groups: $1^{\text {st }}-$ control animals $(C) ; 2^{\text {nd }}-$ control rats that were treated with red wine concentrate enriched with NCP with water for 14 days $(\mathrm{C}+\mathrm{NCP}) ; 3^{\text {rd }}$ - rats with experimental $\mathrm{DM}(\mathrm{DM}) ; 4^{\text {th }}-$ rats with experimental DM that were orally treated with red wine concentrate enriched with NCP with water for 14 days $(\mathrm{DM}+\mathrm{NCP})$.

The obtained concentrate was administrated per os with water at a dose of $45 \mathrm{mg}$ of polyphenols per $1 \mathrm{~kg}$ of body weight, which corresponds to the theoretical average concentration of polyphenols contained in $300 \mathrm{~mL}$ of red wine (which is considered the daily norm for a person weighing $70 \mathrm{~kg}$ ).

Rats from all experimental groups were decapitated under ether anesthesia on the $15^{\text {th }}$ day of the experiment. Extirpation of the heart was performed. The isolated tissues were immediately frozen at $-70{ }^{\circ} \mathrm{C}$.

Homogenization of cardiac muscle tissue was performed on an ice bath at $4^{\circ} \mathrm{C}$ using a manual Potter-Elvehjem homogenizer in the presence of hypotonic $50 \mathrm{mM}$

ISSN 1996-4536 (print) • ISSN 2311-0783 (on-line) • Біологічні Студії / Studia Biologica • 2021 • Том 15 / № 1 • С. 37-48 
Na-K-phosphate buffer $(\mathrm{pH} \mathrm{7.4)}$ at the rate of $10 \mathrm{mg}$ of cardiac muscle tissue in $100 \mu \mathrm{L}$ of a buffer. The studied parameters were determined in the supernatant obtained after centrifugation of the lysates for $5 \mathrm{~min}$ at $10,000 \mathrm{rpm}$.

The concentration of proteins was determined according to the conventional Lowry method [18]. Activity of SOD (EC 1.15.1.1) was determined according to Csóvári [3], CAT (EC 1.11.1.6) - according to Koroliuk [16], GPx (EC 1.11.1.9) - according to Moin [19], glutathione reductase (EC 1.8.1.7; GR) - according to Goldberg [11].

Statistical analysis was carried out using Microsoft Excel. The calculation of the main statistical indicators was performed by direct quantitative data obtained from the research (arithmetic mean $-M$, the standard deviation of the arithmetic mean $-m$ ). To evaluate the reliability of the difference between the statistical characteristics of the two alternative data sets, the Student's ratio was calculated. The difference was considered significant at the indications of reliability $p \geq 0.95$ (significance level $P<0.05$ ).

\section{RESULTS AND DISCUSSION}

ROS are normally produced in cells of aerobic organisms [32]. Their generation intensifies in many pathological conditions, including diabetes [24]. Due to the high reactivity, ROS interact with various cellular components. Reacting with lipids, ROS initiate lipoperoxidation; with DNA - cause point mutations and breakage in the molecule; with proteins - break the peptide bonds and modify the side chains of amino acids. The negative effect of ROS in organisms is counteracted by the antioxidant defense system, the functioning of which prevents generation of free radicals, causes their neutralization and repairing of damages $[17,30]$. There is a certain ambiguity in the data about the state of the antioxidant system in diabetes. An increase of antioxidant enzymes activity and a decrease in the indices of others were detected [1, 10, 11], while in other investigations [8] changes of activity were not detected. It is possible that one of the reasons for such divergences may be fluctuations in blood sugar level, as well as tissuespecific activity of antioxidant enzymes. Cardiomyocytes are significantly affected in diabetes, this leads to the development of cardiopathies [1].

One of the key enzymes of the antioxidant defense system is SOD. This enzyme catalyzes the reaction of dismutation of superoxide radicals $\left(\mathrm{O}_{2}^{-{ }^{-}}\right)$with the formation of hydrogen peroxide and oxygen and, thus, participates in the regulation of free radical processes in living cells at an early stage [17]. According to obtained data (Fig. 1), there was a tendency to reduction of SOD activity by $11 \%$ in cardiac muscle under experimental DM.

A decreased activity of SOD may be caused by glycation of the components of the active site of the enzyme [11]. A lowered SOD activity in DM may be also due to its inactivation by hydrogen peroxide $\left(\mathrm{H}_{2} \mathrm{O}_{2}\right)$ [9]. $\mathrm{H}_{2} \mathrm{O}_{2}$ is formed as a result of glucose autooxidation, therefore, its level is high in diabetic patients. Furthermore, accumulation of superoxide-anion radical $\left(\mathrm{O}_{2}^{--}\right)$and overproduction of Nitrogen oxide (NO) contributes to the excessive formation of peroxynitrite $\left(\mathrm{ONOO}^{-}\right)$in diabetes, which is the mediator of oxidative cell damage. Subsequently, ONOO- deactivates SOD via nitration of the Tyr34 residue in the active site of the enzyme [15, 7].

Under the conditions of concentrate enriched with NCP administration, the tendency to normalization of SOD activity was detected in animals with experimental DM, while no significant changes were identified in control animals (Fig. 1). Polyphenolic

ISSN 1996-4536 (print) • ISSN 2311-0783 (on-line) • Біологічні Студії / Studia Biologica • 2021 • Том 15 / № 1 • C. 37-48 
compounds are known as scavengers of ROS, thus, they have good protective properties [27]. They can "abduct" superoxide anions and other ROS, thereby reducing the generation of several dangerous molecules, including peroxynitrite [6].

CAT is another important antioxidant enzyme. This enzyme is involved in detoxication of $\mathrm{H}_{2} \mathrm{O}_{2}$. It catalyzes its decomposition into water and oxygen [17]. We detected a decrease in the activity of catalase by $16.8 \%$ (Fig. 2) in the cardiac tissue of animals with experimental DM compared to the control.

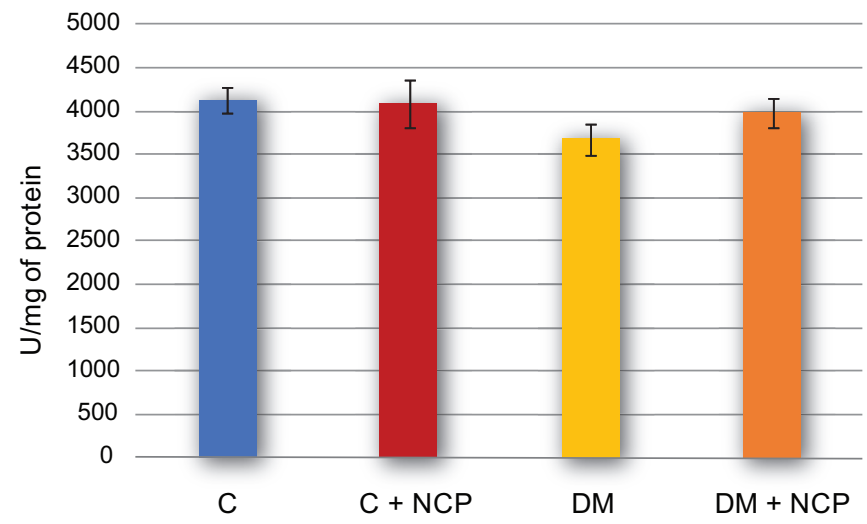

Fig. 1. The activity of superoxide dismutase in cardiac tissue of control animals $(C)$, control animals treated with wine concentrate enriched with natural complex of polyphenols $(C+N C P)$, animals with streptozotocin-induced diabetes mellitus (DM) and animals with experimental diabetes mellitus treated with wine concentrate enriched with natural complex of polyphenols $(\mathrm{DM}+\mathrm{NCP})$

Рис. 1. Активність супероксиддисмутази у тканинах серця контрольних тварин (C), контрольних тварин, яким вводили концентрат виноградного вина, збагачений природним комплексом поліфенолів (C + NCP), тварин зі стрептозотоцин-індукованим цукровим діабетом (DM) і тварин з експериментальним цукровим діабетом, яким вводили концентрат виноградного вина, збагачений природним комплексом поліфенолів (DM + NCP)

A reduced activity of CAT can be associated with dysregulation at gene expression or a decrease in mRNA level. Besides, CAT is over-phosphorylated in diabetes, which can lead to a decrease in enzymatic activity [23]. It is known [28] that NO generation highly intensifies in the pathology. This may affect the antioxidant enzymes activity. For example, NO can bind to the iron-porphyrin complex of CAT to form nitroso-derivatives. The appearance of such complexes prevents binding of $\mathrm{H}_{2} \mathrm{O}_{2}$ in the active site of CAT, as well as its decomposition. Nitrite ions are also able to bind directly to the iron of CAT heme, which can decrease the activity of the enzyme [28].

Under the conditions of administration of concentrate enriched with NCP to animals with DM, there was an increase in CAT activity by $27.7 \%$ compared to the data obtained in diabetes (Fig. 2). However, there were no significant changes detected in CAT activity of cardiomyocytes of control animals after concentrate administration. Polyphenolic compounds of red wine contain resveratrol. This polyphenol can decrease the overphosphorylation of CAT at diabetes, thus, enhancing CAT activity [23].

The glutathione system is also an important part of the antioxidant defense system. It can directly inactivate ROS, supplement and correct errors of "the first line of defense", formed by SOD and CAT [28].

ISSN 1996-4536 (print) • ISSN 2311-0783 (on-line) • Біологічні Студії / Studia Biologica • 2021 • Том 15 / № 1 • C. 37-48 
GPx also neutralizes $\mathrm{H}_{2} \mathrm{O}_{2}$ and has much higher affinity for $\mathrm{H}_{2} \mathrm{O}_{2}$ than that of CAT [28]. GPx and GR activities are reduced in cardiomyocytes in DM by $9 \%$ and $25.5 \%$, respectively (Fig. 3, 4). GPx activity depends on the content of reduced glutathione (GSH), the intracellular concentration of which is maintained by GR. In turn, the functioning of GR is determined by the level of reduced nicotinamide coenzymes. Under conditions of DM, energy depletion can be observed, which causes a shortage of energy substrates. Accordingly, this affects the effectiveness of the antioxidant system [11].

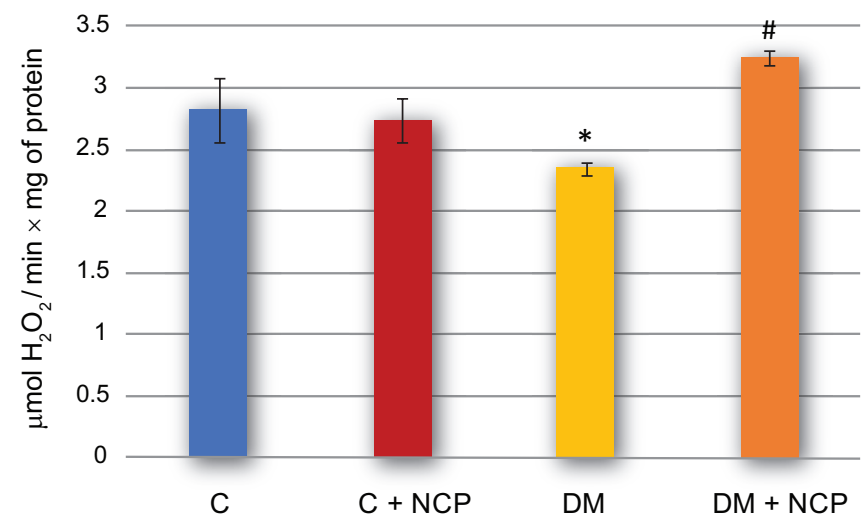

Fig. 2. The activity of catalase in cardiac tissue of control animals $(C)$, control animals treated with wine concentrate enriched with natural complex of polyphenols $(\mathrm{C}+\mathrm{NCP})$, animals with streptozotocininduced diabetes mellitus (DM) and animals with experimental diabetes mellitus treated with wine concentrate enriched with natural complex of polyphenols (DM + NCP)

Comments: * - difference is significant compared to the control group ( $p \geq 0.95$ ); \# - difference is significant compared to the diabetic group $(\mathrm{p} \geq 0.95)$

Рис. 2. Активність каталази у тканинах серця контрольних тварин (C), контрольних тварин, яким вводили концентрат виноградного вина, збагачений природним комплексом поліфенолів (C + NCP), тварин зі стрептозотоцин-індукованим цукровим діабетом (DM) і тварин з експериментальним цукровим діабетом, яким вводили концентрат виноградного вина, збагачений природним комплексом поліфенолів (DM + NCP)

Примітки: * - різниця достовірна порівняно з контролем ( $\geq \geq 0,95)$; \# - різниця достовірна порівняно з діабетом $(p \geq 0,95)$

Under conditions of concentrate enriched with NCP administration, we detected a decrease in GPx activity by $23 \%$ and an increase in GR activity by $36 \%$ in cardiomyocytes of control animals, compared to control (Fig. 3, 4). However, a decrease in GPx activity by $44 \%$ and normalization of GR activity were detected in cardiac muscle of diabetic animals, compared to animals with the pathology after treatment with the concentrate (Fig. 3, 4).

Therefore, the influence of NCP on the activity of enzymes of the glutathione system was investigated. Under hyperglycemic conditions, glucose metabolism is intensified through the polyol and hexosamine pathways. NADPH is a cofactor of an enzyme of polyol pathway aldose reductase. NADPH is also a cofactor of GR. As a result, a decrease in GR activity can be caused due to a lack of the cofactor that is mainly used by enzyme of the polyol pathway in DM [31]. A decreased activity of GR has an impact on GPx activity, while the product of the reaction, GSH, is the substrate of GPx. In addition, an increased metabolism through the hexosamine pathway in diabetes leads to the

ISSN 1996-4536 (print) • ISSN 2311-0783 (on-line) • Біологічні Студії / Studia Biologica • 2021 • Том 15 / № 1 • С. 37-48 


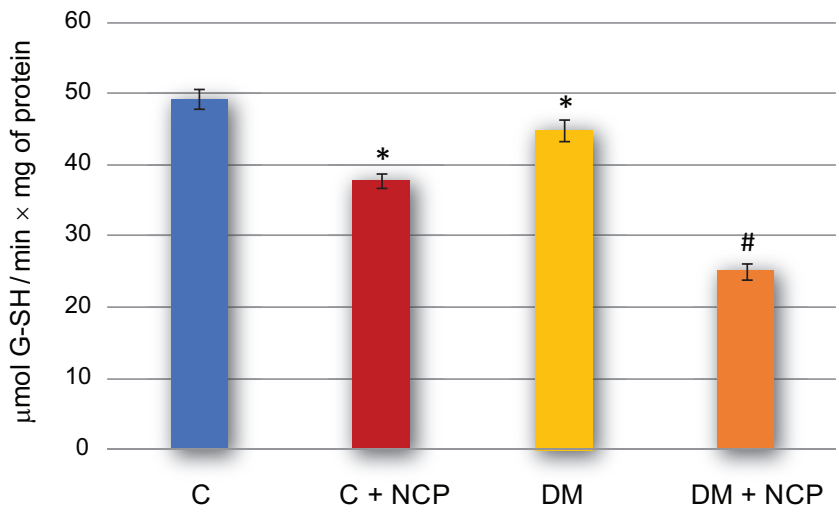

Fig. 3. The activity of glutathione peroxidase in cardiac tissue of control animals (C), control animals treated with wine concentrate enriched with natural complex of polyphenols $(C+N C P)$, animals with streptozotocin-induced diabetes mellitus (DM) and animals with experimental diabetes mellitus treated with wine concentrate enriched with natural complex of polyphenols (DM + NCP)

Comments: * - difference is significant compared to the control group ( $p \geq 0.95)$; \# - difference is significant compared to the diabetic group $(\mathrm{p} \geq 0.95)$

Рис. 3. Активність глутатіонпероксидази у тканинах серця контрольних тварин (С), контрольних тварин, яким вводили концентрат виноградного вина, збагачений природним комплексом поліфенолів $(\mathrm{C}+\mathrm{NCP})$, тварин зі стрептозотоцин-індукованим цукровим діабетом (DM) і тварин з експериментальним цукровим діабетом, яким вводили концентрат виноградного вина, збагачений природним комплексом поліфенолів (DM + NCP)

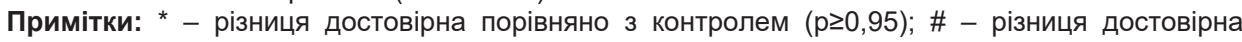
порівняно з діабетом ( $\mathrm{p} \geq 0,95)$

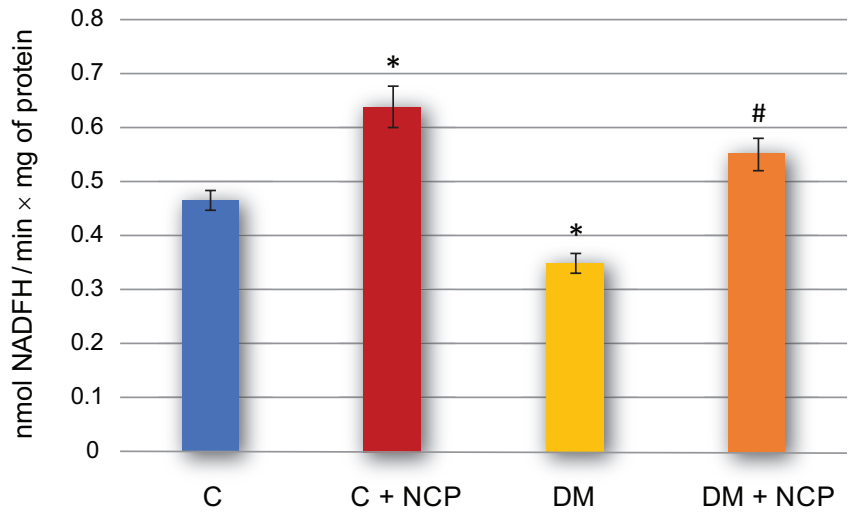

Fig. 4. The activity of glutathione reductase in cardiac tissue of control animals (C), control animals treated with wine concentrate enriched with natural complex of polyphenols $(C+N C P)$, animals with streptozotocin-induced diabetes mellitus (DM) and animals with experimental diabetes mellitus treated with wine concentrate enriched with natural complex of polyphenols (DM + NCP)

Comments: * - difference is significant compared to the control group ( $p \geq 0.95)$; \# - difference is significant compared to the diabetic group $(p \geq 0.95)$

Рис. 4. Активність глутатіонредуктази у тканинах серця контрольних тварин (С), контрольних тварин, яким вводили концентрат виноградного вина, збагачений природним комплексом поліфенолів $(\mathrm{C}+\mathrm{NCP})$, тварин зі стрептозотоцин-індукованим цукровим діабетом (DM) і тварин з експериментальним цукровим діабетом, яким вводили концентрат виноградного вина, збагачений природним комплексом поліфенолів (DM + NCP)

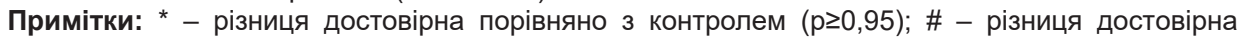
порівняно з діабетом $(p \geq 0,95)$ 
intensification of glycation. This can affect intracellular proteins, such as enzymes of different metabolic pathways [31].

Polyphenols reduce glucose concentration, which restores the level of NADPH available for GR. Hence, the activity of the studied enzyme increases. We can also hypothesize that GPx activity decreases after treatment with the studied concentrate because of the antioxidant action of polyphenols. These compounds due to scavenger activity reduce the level of peroxides that can serve as substrates for GPx. It can be assumed that the level of peroxides can be reduced because of an increased activity of other enzymes, such as catalase, under the same conditions.

An antioxidant deficit in cardiac cells, especially a reduced activity of SOD, CAT, GPx, and GR, leads to myocardial infarction [2]. Intensification of fatty acid $\beta$-oxidation due to a high level of fatty acids in DM leads to an elevation of mitochondrial inner membrane potential and stimulates ROS production [20]. An increased generation of ROS also has a negative impact on cardiac cells [2]. Thus, the studied concentrate has not only the antioxidant, but also the cardioprotective properties, and can be the basis for the creation of food additives or drugs enriched with polyphenolic compounds for complex therapy of DM.

\section{CONCLUSIONS}

A decrease in the activity of enzymes of the antioxidant defense system in cardiac muscle under the conditions of DM was detected. That is the evidence of the development of oxidative-nitrative stress in cardiomyocytes in the studied pathology, which is one of the main causes of cardiovascular diseases.

Normalization of SOD and CAT activities after treatment with red wine concentrate enriched with NCP at diabetic condition indicates antioxidant, and, subsequently, cardioprotective effects of these compounds.

The glutathione system was violated at DM. Treatment with concentrate enriched with NCP caused an increase of GR activity and a decrease in GPx activity. Different effects of polyphenolic compounds on elements of the glutathione system in DM were found.

The molecular mechanisms of action of polyphenols from wine require further research. Besides, it is beyond doubt that such natural complexes of polyphenolic compounds show a corrective effect, and, therefore, can serve as a basis for new antidiabetic drugs.

\section{COMPLIANCE WITH ETHICAL STANDARDS}

Conflict of Interest: The authors declare that the research was conducted in the absence of any commercial or financial relationships that could be construed as a potential conflict of interest.

Human Rights: This article does not contain any studies with human subjects performed by the any of the authors.

Animal studies: All institutional, national and institutional guidelines for the care and use of laboratory animals were followed. 
1. Aju B.Y., Rajalakshmi R., Mini S. Protective role of Moringa oleifera leaf extract on cardiac antioxidant status and lipid peroxidation in streptozotocin induced diabetic rats. Heliyon, 2019; 5(12): e02935.

Crossref $\bullet$ PubMed $\bullet$ PMC $\bullet$ Google Scholar

2. Cebova M., Pechanova O. Protective effects of polyphenols against ischemia/reperfusion injury. Molecules, 2020; 25(15): 3469.

Crossref $\bullet$ PubMed $\bullet$ PMC $\bullet$ Google Scholar

3. Csóvári S., Andyal T.D., Shtirenher D. Determination of antioxidant properties of the blood and their diagnostic significance in the elderly. Lab Delo, 1991; 10: 9-13. (In Russian)

PubMed

4. Diabetes mellitus. Intranet, Ternopil State Medical University.

URL: http://intranet.tdmu.edu.ua/data/cd/Ped_FPO/html/data/chapter_9/ch_9.2.html

(viewed on 22.11.2020). (In Ukrainian)

5. Diabetes. World Health Organization, World Health Organization.

URL: https://www.who.int/news-room/facts-in-pictures/detail/diabetes (viewed on 05.12.2020)

6. Drel V.R., Hnatush A.R., Yalaneckyy A.Ya., Herzhykova V.H., Mizin V.I., Zagoruyko V.A., Sybirna N.O. Protective effect of grape wines in nitrosative stress caused by experimental diabetes mellitus. Ukr Biokhim Zh, 2010; 82(1): 108-116. (In Ukrainian)

PubMed • Google Scholar

7. Drel V.R., Sybirna N. Protective effects of polyphenolics in red wine on diabetes associated oxidative/nitrative stress in streptozotocin-diabetic rats. Cell Biology International, 2010; 34(12): 1147-1153.

Crossref $\bullet$ PubMed $\bullet$ Google Scholar

8. Đurašević S., Jasnić N., Prokić M., Grigorov I., Martinović V., Đorđević J., Pavlović S. The protective role of virgin coconut oil on the alloxan-induced oxidative stress in the liver, kidneys and heart of diabetic rats. Food Funct, 2019; 10: 2114-2124.

Crossref $\bullet$ PubMed $\bullet$ Google Scholar

9. Dworzański J., Strycharz-Dudziak M., Kliszczewska E., Kiełczykowska M., Dworzańska A., Drop B., Polz-Dacewicz M. Glutathione peroxidase (GPx) and superoxide dismutase (SOD) activity in patients with diabetes mellitus type 2 infected with Epstein-Barr virus. PLoS ONE, 2020; 15(3): e0230374.

Crossref $\bullet$ PubMed $\bullet$ PMC $\bullet$ Google Scholar

10. Furka O.B., Ivanusa I.B., Mykhalkiv M.M., Klishch I.M. Changes of some indices of antioxidant system in rats with type 2 diabetes mellitus and acetaminophen toxic lesions. Medical and Clinical Chemistry, 2017; 19(1): 25-30. (In Ukrainian)

Crossref $\bullet$ Google Scholar

11. Gnatush A.R., Drel V.R., Yalaneckyy A.Ya., Mizin V.I., Zagoruyko V.A, Gerzhykova V.G., Sybirna N.O. The antioxidant effect of natural polyphenolic complexes of grape wine in the rat retina under streptozotocin-induced diabetes mellitus. Studia Biologica, 2011; 5(1): 61-72. (In Ukrainian)

Crossref $\bullet$ Google Scholar

12. Goldberg D.M., Spooner R.J. Glutathione Reductase. In: H.U. Bergmeyer, J. Bergmeyer, M. Grassl, Eds. Methods in Enzymatic Analysis, 3rd ed. Weinheim: Verlag Chemie, 1983; P. 258-265.

13. Haidara M.A., Yassin H.Z., Rateb M. Role of oxidative stress in development of cardiovascular complications in diabetes mellitus. Current Vascular Pharmacology, 2006; 4(3): 215-227.

Crossref $\bullet$ PubMed $\bullet$ Google Scholar

14. Ighodaro O.M. Molecular pathways associated with oxidative stress in diabetes mellitus. Biomedicine \& Pharmacotherapy, 2018; 108: 656-662.

Crossref $\bullet$ PubMed $\bullet$ Google Scholar

ISSN 1996-4536 (print) • ISSN 2311-0783 (on-line) • Біологічні Студії / Studia Biologica • 2021 • Том 15 / № 1 • С. 37-48 
15. Kitada M., Xu J., Ogura Y., Monno I., Koya D. Manganese superoxide dismutase dysfunction and the pathogenesis of kidney disease. Frontiers in Physiology, 2020; 11: 1-16.

Crossref $\bullet$ PubMed $\bullet$ PMC $\bullet$ Google Scholar

16. Koroliuk M.A., Ivanova L.I., Mayorova I.G. A method of determining catalase activity. Lab Delo, 1988; 1: 16-19. (In Russian)

PubMed • Google Scholar

17. Lavryshyn Y.Y., Varkholyak I.S., Martyschuk T.V., Guta Z.A. The Biological significance of the antioxidant defense system of animals body. Scientific Messenger of LNU of Veterinary Medicine and Biotechnologies. Series: Veterinary Sciences, 2016; 18(2): 100-111. (In Ukrainian)

Crossref $\bullet$ Google Scholar

18. Lowri O.H., Rosenbraugh M.J., Farr A.L., Randall R.J. Protein measurement with the Folin phenol reagent. Journal of Biological Chemistry, 1951; 193(1): 265-275. Crossref $\bullet$ PubMed $\bullet$ Google Scholar

19. Moin V.M. A simple and specific method for determining glutathione peroxidase activity in erythrocytes. Lab Delo, 1986; (12): 724-727. (In Russian)

PubMed • Google Scholar

20. Peoples J.N., Saraf A., Ghazal N., Pham T.T., Kwong J.Q. Mitochondrial dysfunction and oxidative stress in heart disease. Exp Mol Med, 2019; 51: 1-13.

Crossref $\bullet$ PubMed $\bullet$ PMC • Google Scholar

21. Pitocco D., Zaccardi F., Di Stasio E. Oxidative stress, nitric oxide, and diabetes. Rev Diabet Stud, 2010; 7(1): 15-25.

Crossref $\bullet$ PubMed $\bullet$ PMC $\bullet$ Google Scholar

22. Sabadashka M., Hnatush A., Sybirna N. Qualitative and quantitative composition of polyphenols in Cabernet Sauvignon dry red wine concentrates. Visnyk of Lviv University. Series Biology, 2014; 65: 77-85. (In Ukrainian) Google Scholar

23. Sadi G., Bozan D., Yildiz H.B. Redox regulation of antioxidant enzymes: post-translational modulation of catalase and glutathione peroxidase activity by resveratrol in diabetic rat liver. Molecular and Cellular Biochemistry, 2014; 393(1-2): 111-122.

Crossref $\bullet$ PubMed $\bullet$ Google Scholar

24. Santos A.L., Sinha S., Lindner A.B. The good, the bad, and the ugly of ROS: new insights on aging and aging-related diseases from eukaryotic and prokaryotic model organisms. Oxidative Medicine and Cellular Longevity, 2018; 2018: 1-23.

Crossref • PubMed • PMC • Google Scholar

25. Shchegol I.M. Diabetes mellitus. Nursing, 2019; (1): 52-54. (In Ukrainian)

Crossref $\bullet$ Google Scholar

26. Singleton V.L., Orthofer R., Lamuela-Raventós R.M. Analysis of total phenols and other oxidation substrates and antioxidants by means of Folin-Ciocalteu reagent. Methods in Enzymology, 1999; 299: 152-178.

Crossref $\bullet$ Google Scholar

27. Świętek M., Lu Y.C., Konefał R., Ferreira L.P., Cruz M.M., Ma Y.H., Horák D. Scavenging of reactive oxygen species by phenolic compound-modified maghemite nanoparticles. Beilstein Journal of Nanotechnology, 2019; 10: 1073-1088.

Crossref $\bullet$ PubMed $\bullet$ PMC $\bullet$ Google Scholar

28. Sybirna N.O., Datsyuk L.O., Datsyuk U.V. Pat. U201313977 Ukraine. Method of preparation of red wine natural polyphenolic complex concentrate. Applicant LNU I. Franko; Appl. 2.02.2013. 5 p. (Publication decision 26.02.2014). (In Ukrainian)

29. Sybirna N.O., Mayevska O.M., Barska M.L. Investigation of certain biochemical parameters under conditions of oxidative stress. Lviv: I. Franko LNU, 2006. 60 p. (In Ukrainian)

Google Scholar

ISSN 1996-4536 (print) • ISSN 2311-0783 (on-line) • Біологічні Студії / Studia Biologica • 2021 • Том 15 / № 1 • С. 37-48 
30. Unuofin J.O., Lebelo S.L. Antioxidant effects and mechanisms of medicinal plants and their bioactive compounds for the prevention and treatment of type 2 diabetes: an updated review. Oxidative Medicine and Cellular Longevity, 2020; 2020: 1-36.

Crossref $\bullet$ PubMed $\bullet$ PMC $\bullet$ Google Scholar

31. Wojcik M., Krawczyk M., Wozniak L.A. Antidiabetic activity of curcumin. Nutritional and therapeutic interventions for diabetes and metabolic syndrome. Cambridge: Academic Press, 2018: 385-401.

Crossref $\bullet$ Google Scholar

32. Yaribeygi H., Sathyapalan T., Atkin S.L., Sahebkar A. Molecular mechanisms linking oxidative stress and diabetes mellitus. Oxidative Medicine and Cellular Longevity, 2020; 2020: 1-13. Crossref $\bullet$ PubMed $\bullet$ PMC $\bullet$ Google Scholar

\title{
КОРИГУЮЧИЙ ЕФЕКТ КОНЦЕНТРАТУ ЧЕРВОНОГО ВИНОГРАДНОГО ВИНА, ЗБАГАЧЕНОГО ПРИРОДНИМ КОМПЛЕКСОМ ПОЛІФЕНОЛІВ, НА АКТИВНІСТЬ ФЕРМЕНТІВ АНТИОКСИДАНТНОГО ЗАХИСТУ В СЕРЦЕВОМУ М'ЯЗІ ЗА ЕКСПЕРИМЕНТАЛЬНОГО ЦУКРОВОГО ДІАБЕТУ
}

\author{
Д. Ю. Герцик ${ }^{1 *}$ М. В. Сабадашка ${ }^{1}$, Л. В. Капрельяни ${ }^{2}$, Н. О. Сибірна \\ 1 Львівський національний університет імені Івана Франка \\ вул. Грушевського, 4, Львів 79005, Україна \\ 2 Одеська національна академія харчових технологій \\ вул. Канатна, 112, Одеса 65039, Україна \\ *Кореспондуючий автор e-mail: Dariya.Hertsyk@Inu.edu.ua
}

Вступ. Цукровий діабет супроводжується оксидативно-нітративним стресом, який виникає не лише у результаті посилення утворення активних фрорм оксигену та нітрогену за умов цієї патології, але й через порушення діяльності системи антиоксидантного захисту, зокрема, її ензиматичної ланки. Це є причиною змін морфофрункціонального стану клітин, органів і організму загалом. Вільні радикали залучені до деструкції клітин підшлункової залози, зокрема, за цукрового діабету 1-го типу, що призводить до ще більшого скорочення інсулінової секреції, погіршення перебігу хвороби і виникнення діабетичних ускладнень. До ускладнень за цукрового діабету належать часто діагностовані серцево-судинні захворювання. Тому перспективним є застосування препаратів, що характеризуються не лише цукрознижувальними властивостями, для нормалізації глікемії за цукрового діабету, але й антиоксидантними властивостями, для нормалізації оксидантно/антиоксидантного балансу за досліджуваної патології. Науковці усього світу приділяють чимало уваги дослідженням речовин із такими властивостями, зокрема природним поліфенольним сполукам винограду, які також характеризуються імуномодулюючими властивостями.

Матеріали та методи. У дослідженні використовували тканини серцевого м'яза контрольних щурів, контрольних тварин, яким вводили концентрат природного поліфенольного комплексу з виноградного вина, тварин зі стрептозотоцин-індукованим цукровим діабетом і щурів з експериментальним цукровим діабетом, яким вводили концентрат виноградного вина, збагачений природним комплексом поліфренолів. Активність каталази, супероксиддисмутази, глутатіонпероксидази та 
глутатіонредуктази визначали для дослідження коригуючого ефекту природного комплексу поліфенолів із червоного виноградного вина на стан ензиматичної ланки системи антиоксидантного захисту.

Результати. Встановлено нормалізаціюактивностікаталази, супероксиддисмутази та зміну активності фрерментів циклу глутатіону при пероральному введенні впродовж 14 днів концентрату поліфенольних сполук щурам зі стрептозотоциніндукованим цукровим діабетом.

Висновки. Отримані результати підтверджують гіпотезу про антиоксидантну дію досліджуваного концентрату і здатність природного комплексу поліфенолів з червоного виноградного вина стати основою нових препаратів, що коригуватимуть діабет-індуковані порушення.

Ключові слова: цукровий діабет, поліфенольні сполуки, антиоксидантна система 